\title{
Influence of the metal sites of M-N-C (M = Co, Fe, Mn) catalysts derived from metalloporphyrins in ethylbenzene oxidation
}

\author{
Lingling $\mathrm{Fu}^{\text {a, }}$, Yijuan Lu ${ }^{\mathrm{a}}$, Zhigang Liu a,*, Runliang Zhu ${ }^{\mathrm{b}}$ \\ a State Key Laboratory of Chemo/Biosensing and Chemometrics, College of Chemistry and Chemical Engineering, Hunan University, Changsha 410082, \\ Hunan, China \\ ${ }^{\mathrm{b}}$ Guangzhou Institute of Geochemistry, Chinese Academy of Sciences, Guangzhou 510640, Guangdong, China
}

\section{A R T I C L E I N F O}

Article history:

Received 15 October 2015

Accepted 24 November 2015

Published 5 March 2016

Keywords:

$\mathrm{M}$ (cobalt, iron, manganese)-N-C

Transition metal

Nitrogen-doped carbon

Porphyrin

Ethylbenzene oxidation

\section{A B S T R A C T}

Transition metal catalysts $\mathrm{M}-\mathrm{N}-\mathrm{C}(\mathrm{M}=\mathrm{Co}, \mathrm{Fe}, \mathrm{Mn})$ were synthesized by a template-free method by heating meso-tetraphenyl porphyrins (i.e. CoTPP, FeTPPCl, MnTPPCl) precursors. The catalysts were characterized by $\mathrm{N}_{2}$ adsorption-desorption, thermogravimetry, high-resolution transmission electron microscopy, and Raman and X-ray photoelectron spectroscopy. The selective oxidation of ethylbenzene with molecular oxygen under a solvent-free condition was carried out to explore the catalytic performance of the M-N-Cs, which exhibited different catalytic performance. That was ascribed to the difference in $\mathrm{M}(\mathrm{Co}, \mathrm{Fe}, \mathrm{Mn})$ and different graphitization degree forming during the heating process, in which $\mathrm{M}(\mathrm{Co}, \mathrm{Fe}, \mathrm{Mn})$ might have different catalytic activity on the formation of the $\mathrm{M}-\mathrm{N}-\mathrm{C}$ catalyst. All the $\mathrm{M}-\mathrm{N}-\mathrm{C}$ composites had remarkable recyclability in the selective oxidation of ethylbenzene.

(C) 2016, Dalian Institute of Chemical Physics, Chinese Academy of Sciences. Published by Elsevier B.V. All rights reserved.

\section{Introduction}

Transition metal catalysts such as $\mathrm{Co}, \mathrm{Fe}, \mathrm{Ni}$, and $\mathrm{Mn}$ have attracted intensive research because of their abundance and economical utilization [1-4]. These transition metals have been utilized in electrocatalysis and synthesized to replace $\mathrm{Pt}$, which is limited by its rareness, high price, and low methanol resistance [5]. Due to their superior properties, nitrogen-doped carbon (N-C) supported non-precious catalysts have been extensively studied [6-8]. M-N-Cs can be made from a variety of different metals, nitrogen and carbon precursors such as ammonia, acetonitrile and chelating agents and macrocycles (porphyrins or phthalocyanines) by high heat treatment [9].

Wang et al. [10] synthesized ultrafine dispersed iron ox- ide-based nanoparticles (NPs) embedded in nitrogen-doped carbon by a one-pot method with D-glucosamine hydrochloride as the carbon and nitrogen source, melamine as the soft template, and $\mathrm{Fe}\left(\mathrm{NO}_{3}\right)_{3} \cdot 6 \mathrm{H}_{2} \mathrm{O}$ as the metal source. The hybrid catalyst exhibited high activity and excellent durability for the hydrogen evolution reaction (HER) in alkaline solution. They pointed out that the high HER activity of the hybrid catalyst was due to the strong interaction between Fe-based NPs and $\mathrm{N}$-doped graphitic carbon, especially the synergistic effect of $\mathrm{Fe}$ and $\mathrm{Fe}_{2} \mathrm{O}_{3}$. Herrmann et al. [11] modified Co-based TMPP by adding various metal oxalates where the oxalates behaved as a structure forming agent to provide a nano-scaled template for the carbonization of the CoTMPP. After removing the oxalates by an etching step, catalysts with enhanced specific surface

\footnotetext{
*Corresponding author. Tel: +86-731-88823327; E-mail: liuzhigang@hnu.edu.cn

This work was supported by the National Natural Science Foundation of China $(21103045,1210040,1103312)$, State Key Laboratory of Heavy Oil at China University of Petroleum (SKCHOP201504), and Key Laboratory of Mineralogy and Metallogeny of the Chinese Academy of Sciences at Guangzhou Institute of Geochemistry (KLMM20150103).

DOI: 10.1016/S1872-2067(15)61029-4 | http://www.sciencedirect.com/science/journal/18722067 | Chin. J. Catal., Vol. 37, No. 3, March 2016
} 
area were obtained.

Metalloporphyrins with a unique carbon-rich macrocycle and metal-nitrogen coordination, especially cobalt porphyrin, iron porphyrin, and manganese porphyrin, which are porphyrins with transition metal elements, are attractive precursors for the one-step synthesis of M-N-C catalysts [12]. The catalytic performance of M-N-Cs in the selective oxidation of arylalkanes has been explored $[13,14]$.

Here, we synthesized transition metal catalysts embedded in nitrogen-doped carbon $\mathrm{M}-\mathrm{N}-\mathrm{C}(\mathrm{M}=\mathrm{Co}, \mathrm{Fe}, \mathrm{Mn})$ by a template-free method by heating different meso-tetraphenyl porphyrins (CoTPP, FeTPPCl, MnTPPCl) precursors. These catalysts were characterized by $\mathrm{N}_{2}$ adsorption-desorption, thermogravimetry (TG), transmission electron microscopy (TEM), high-resolution TEM (HRTEM), and Raman and X-ray photoelectron spectroscopy (XPS). The selective oxidation of ethylbenzene with molecular oxygen under solvent-free conditions was carried out to explore the catalytic performance of the M-N-Cs.

\section{Experimental}

\subsection{Preparation of the catalysts}

$\mathrm{CoCl}_{2} \cdot 6 \mathrm{H}_{2} \mathrm{O}, \quad \mathrm{FeCl}_{2} \cdot 4 \mathrm{H}_{2} \mathrm{O}, \mathrm{MnCl}_{2} \cdot 4 \mathrm{H}_{2} \mathrm{O}$, benzaldehyde, $p$ formylbenzoic acid, propanoic acid, dichloromethane, anhydrous $N, N^{\prime}$-dimethyl formamide (DMF), ethanol, ethylbenzene, bromobenzene, and 1, 4-dichlorobenzene were obtained commercially and used without further purification. Pyrrole was distilled before utilization.

Typically [15], distilled pyrrole (4.69 g, $70.0 \mathrm{mmol}$ ) was added dropwise into a three-neck flask containing a mixture of propanoic acid (250 $\mathrm{mL}$ ), benzaldehyde (5.56 g, $52.5 \mathrm{mmol})$, and 4-carboxy benzaldehyde (2.62 g, $17.5 \mathrm{mmol}$ ), and then refluxed for $1 \mathrm{~h}$. The product was cooled overnight, then filtered and purified. This was denoted as TPP.

The TPP sample (1.0 g, $1.6 \mathrm{mmol}$ ) was dissolved in $100 \mathrm{~mL}$ DMF. After loading $10.5 \mathrm{mmol}$ of $\mathrm{CoCl}_{2} \cdot 6 \mathrm{H}_{2} \mathrm{O}$ in batches, the mixture was heated to reflux under stirring until the meso-triphenyl porphyrin was exhausted. After cooling overnight, the mixture was filtered and washed repeatedly with deionized water. The product Co(II) meso-tetraphenyl porphyrin was denoted as CoTPP.

For the synthesis of Fe(III) meso-tetraphenyl porphyrin (FeTPPCl), $\mathrm{FeCl}_{2} \cdot 4 \mathrm{H}_{2} \mathrm{O}$ was introduced to the synthesis. After the reflux, when the mixture was cooled to $100{ }^{\circ} \mathrm{C}, 100 \mathrm{~mL} \mathrm{HCl}$ solution $(\mathrm{pH}=1)$ was added. Then the mixture was stirred for another $30 \mathrm{~min}$ before cooling to ambient temperature. The post-treatment was the same as that for CoTPP.

The synthesis of $\mathrm{Mn}$ (III) meso-tetraphenyl porphyrin MnTPPCl was similar to CoTPP, but the added metal salt was $\mathrm{MnCl}_{2} \cdot 4 \mathrm{H}_{2} \mathrm{O}$ instead of $\mathrm{CoCl}_{2} \cdot 6 \mathrm{H}_{2} \mathrm{O}$.

A portion of metal porphyrin was ground and placed in the porcelain boat and heated directly in $\mathrm{N}_{2}$ flow with a heating rate of $10^{\circ} \mathrm{C} / \mathrm{min}$ and kept at $800{ }^{\circ} \mathrm{C}$ for $1 \mathrm{~h}$. The catalyst was ground well and denoted as $\mathrm{M}-\mathrm{N}-\mathrm{C}(\mathrm{M}=\mathrm{Co}, \mathrm{Fe}, \mathrm{Mn})$.

\subsection{Characterization}

The specific surface area was measured by $\mathrm{N}_{2}$ adsorption-desorption at $-196{ }^{\circ} \mathrm{C}$ on a NOVA $1000 \mathrm{e}$ apparatus from Quantachrome Instruments. The sample was degassed at 300 ${ }^{\circ} \mathrm{C}$ for $3 \mathrm{~h}$ prior to the experiment. The Brunauer-Emmett-Teller (BET) and Barrett-Joyner-Halenda (BJH) methods were used to determine the specific surface areas and pore sizes of the samples, respectively. TEM and HRTEM studies were obtained on a JEM-3010 high-resolution transmission electron microscope operating at $200 \mathrm{kV}$. TG was analyzed on a NETZSCH apparatus. Raman measurements were performed at ambient conditions using a $632 \mathrm{~nm}$ laser on a Labram-010 apparatus. XPS measurements were evaluated on a RBD upgraded PHI-5000C ESCA system (PerkinElmer) with $\mathrm{Mg} K_{\alpha}$ radiation $(h v=1253.6 \mathrm{eV})$ or Al $K_{\alpha}$ radiation $(h v=1486.6 \mathrm{eV}$ ). The binding energies were calibrated using the $\mathrm{C} 1 \mathrm{~s}$ peak at $284.6 \mathrm{eV}$ as reference.

\subsection{Catalytic performance test}

The selective oxidation of ethylbenzene with molecular oxygen as oxidant was conducted in a $50 \mathrm{~mL}$ autoclave. Ethylbenzene $(10 \mathrm{~mL}$ ) and catalyst $(30 \mathrm{mg}$ ) were loaded in the reactor and then sealed and the pressure raised to $0.8 \mathrm{MPa}$ with $\mathrm{O}_{2}$. The temperature was increased to $120^{\circ} \mathrm{C}$ and kept for $5 \mathrm{~h}$.

The products were analyzed by a gas chromatograph (Shimadzu GC-2014 equipped with a capillary column (RTX-5)) using a flame ionization detector with the internal standard method using bromobenzene and 1, 4-dichlorobenzene as reference. The recovered catalyst was obtained by centrifugation, then washed with ethanol and dried at $80^{\circ} \mathrm{C}$ in air.

\section{Results and discussion}

\section{1. $N_{2}$ adsorption}

$\mathrm{N}_{2}$ adsorption-desorption isotherms and the pore size distribution curves of the M-N-Cs are shown in Fig. 1. It showed that the amount of adsorbed $\mathrm{N}_{2}$ increased at a high $p / p_{0}(>0.9)$ without an adsorption limit for Co-N-C and Fe-N-C. According to the IUPAC classification, the $\mathrm{N}_{2}$ adsorption isotherms were Type IV and indicated the presence of mesopores. There was a relatively large adsorption-desorption hysteresis loop of the $\mathrm{H} 3$ type at $p / p_{0}>0.4$, which was due to the capillary condensation of $\mathrm{N}_{2}$ in the slit-shaped nanopores [16]. However, the isotherm of Mn-N-C was not smooth. From Table 1, it can be seen that the specific surface areas of the M-N-Cs exhibited the order Co-N-C > Fe-N-C > Mn-N-C, as did the total pore volume, $D_{\mathrm{p}}$, and $\mathrm{d} V(d)$. In our earlier report, we found that the specific surface area of $\mathrm{Co}-\mathrm{N}-\mathrm{C}$ increased with elevated temperature, which was caused by the different calcination degree [17]. Thus, it can be concluded that the M-N-Cs ( $\mathrm{M}=\mathrm{Co}, \mathrm{Fe}, \mathrm{Mn}$ ) had different calcination degree, which may be attributed to the different catalytic performance of the transition metal in the formation of the $\mathrm{N}-\mathrm{C}$. 

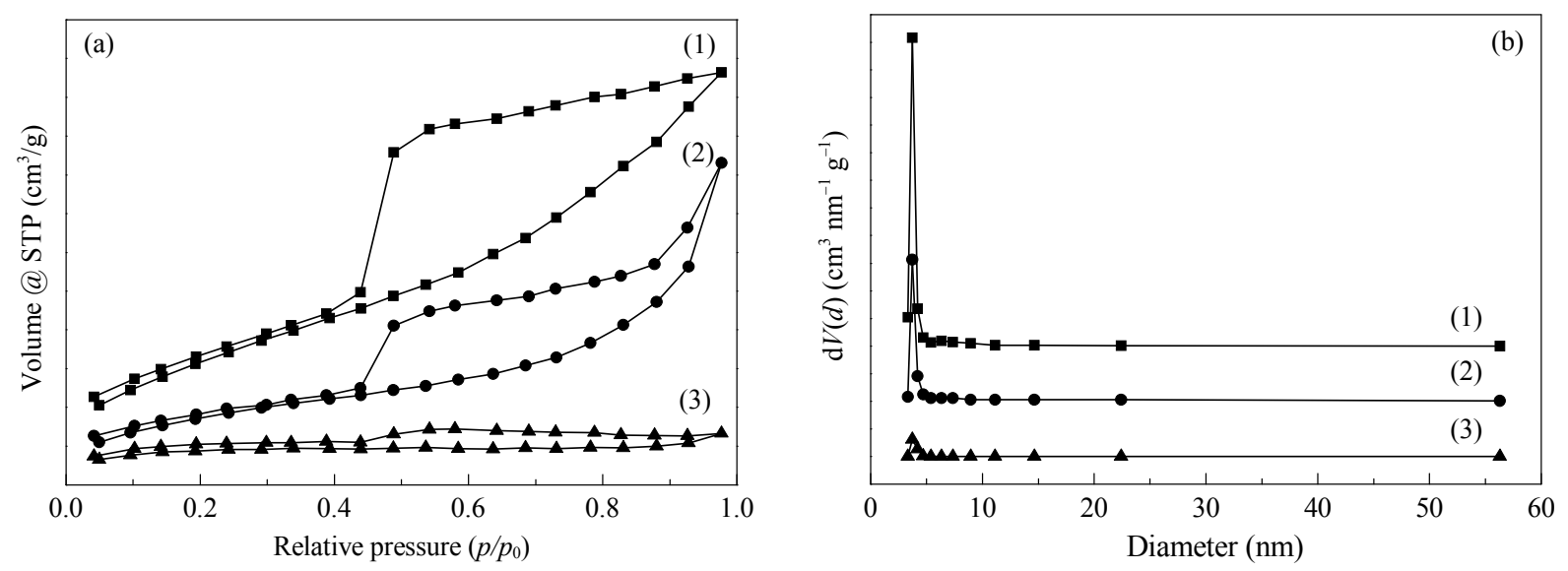

Fig. 1. $\mathrm{N}_{2}$ adsorption-desorption isotherms (a) and pore size distribution (b) of Co-N-C (1), Fe-N-C (2), and Mn-N-C (3).

Table 1

Physical properties of the M-N-Cs ( $\mathrm{M}=\mathrm{Co}, \mathrm{Fe}, \mathrm{Mn})$.

\begin{tabular}{lcccc}
\hline Catalyst & $A_{\mathrm{BET}}{ }^{\mathrm{a}}\left(\mathrm{m}^{2} / \mathrm{g}\right)$ & $V_{\text {tot }^{\mathrm{b}}}\left(\mathrm{cm}^{3} / \mathrm{g}\right)$ & $D_{\mathrm{p}} \mathrm{c}(\mathrm{nm})$ & $\mathrm{d} V(d)\left(\mathrm{cm}^{3} \mathrm{~nm}^{-1} \mathrm{~g}^{-1}\right)$ \\
\hline Co-N-C & 193.8 & 0.21 & 3.73 & 0.28 \\
Fe-N-C & 182.5 & 0.19 & 3.73 & 0.13 \\
Mn-N-C & 147.0 & 0.08 & 3.68 & 0.02 \\
\hline
\end{tabular}

a Surface areas calculated using the BET method.

b Total pore volumes estimated from the $\mathrm{N}_{2}$ adsorption isotherm at $p / p_{0}$ $=0.98$.

c Mesopore diameters calculated from the $\mathrm{N}_{2}$ desorption branch using the BJH method.

\subsection{TG analysis}

TG analysis was conducted to further investigate the structure evolution of the transition metal porphytins with increasing temperature (Fig. 2). Taking CoTPP as an example, there was a loss of water of crystallization at $95^{\circ} \mathrm{C}$ with a mass loss of $6 \%$. The total mass loss was $81 \%$ from the TG curve. The curve showed decomposition temperatures at 410,513 , and $746{ }^{\circ} \mathrm{C}$, which indicated that CoTPP decomposed by steps and the different stages are associated with the sequential thermal degradation of the porphyrin macrocycles, that is, detachment of phenyl rings from pyrole rings, rupture and detachment of

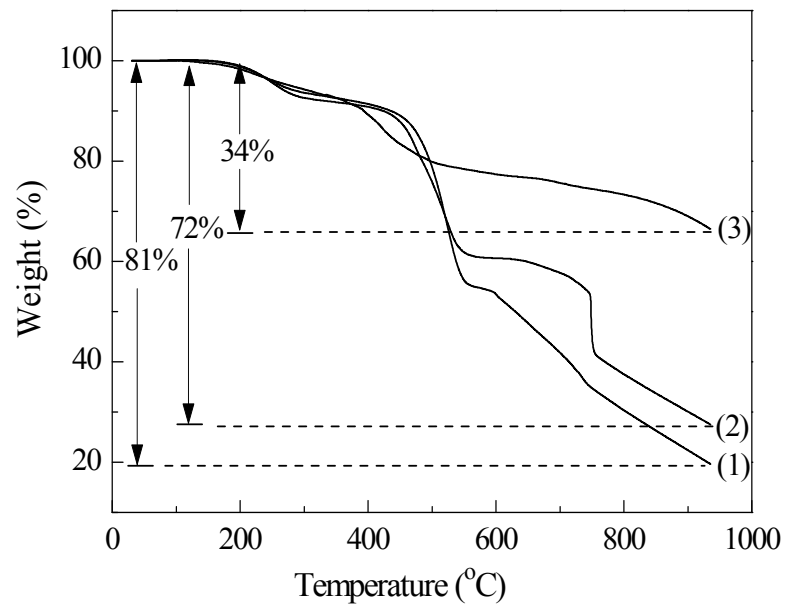

Fig. 2. TG curves of CoTPP (1) , FeTPPCl (2), and MnTPPCl (3). cobalt from pyrole rings, cleavage of phenyl rings, and decomposition of the remaining organic fragment [18,19]. The TG curve of FeTPPCl was similar to that of CoTPP but had less total mass loss (72\%). As for MnTPPCl, the stage of the loss of crystallization water was almost similar to that of CoTPP and FeTPPCl. However, after that, the decomposition temperatures were 331,497 , and $688^{\circ} \mathrm{C}$, which were lower. The total mass loss was only $34 \%$ until the end stage. This indicated that the thermal stability of MnTPPCl was better than that of CoTPP and FeTPPCl.

\subsection{TEM results}

The morphology and structure of the Co-N-C, Fe-N-C, and $\mathrm{Mn}-\mathrm{N}-\mathrm{C}$ composites were examined by TEM and HRTEM. The results are presented in Fig. 3. As shown in Fig. 3(a), the TEM image of Co-N-C showed that Co nanoparticles were embedded in graphite carbon and amorphous carbon (Fig. 3(d)). It can be clearly seen that the graphitic spiral structures were twisted and spiral, which showed ringed graphitic layers had formed. However, the fringes of graphitic carbon were rarely seen in Fe-N-C (Fig. 3(b) and (e)) and Mn-N-C (Fig. 3(c) and (f)). In $\mathrm{Mn}-\mathrm{N}-\mathrm{C}$, particularly, the Mn nanoparticles were embedded in a flat sheet-like structure composed of amorphous carbon (Fig. $3(\mathrm{c})$ ). It was clearly observed that the $\mathrm{M}-\mathrm{N}-\mathrm{C}$ composites (Co-N-C, Fe-N-C and Mn-N-C) possessed different graphitization degree. Besides, the metal particle size in Co-N-C is about $43 \mathrm{~nm}$. In Fe-N-C, the metal compound particles are about 114 $\mathrm{nm}$, while that it is $\sim 20 \mathrm{~nm}$ for Mn-N-C. This observation was in agreement with the $\mathrm{N}_{2}$ adsorption-desorption and $\mathrm{TG}$ results.

\subsection{Raman results}

Raman spectroscopy was used to study the graphitization process and chemical bonding state of the pyrolyzed metal porphyrins (Fig. 4). All these M-N-C materials have an obvious D band at $1328 \mathrm{~cm}^{-1}$, which is associated with defects, and a G band at $1593 \mathrm{~cm}^{-1}$, which is due to graphitic carbon (Fig. 4) [20]. The intensity ratio of $\mathrm{D}$ and $\mathrm{G}$ bands, $I(\mathrm{D}) / I(\mathrm{G})$, is used to evaluate the disorder in the materials. The higher $I(D) / I(G)$ 


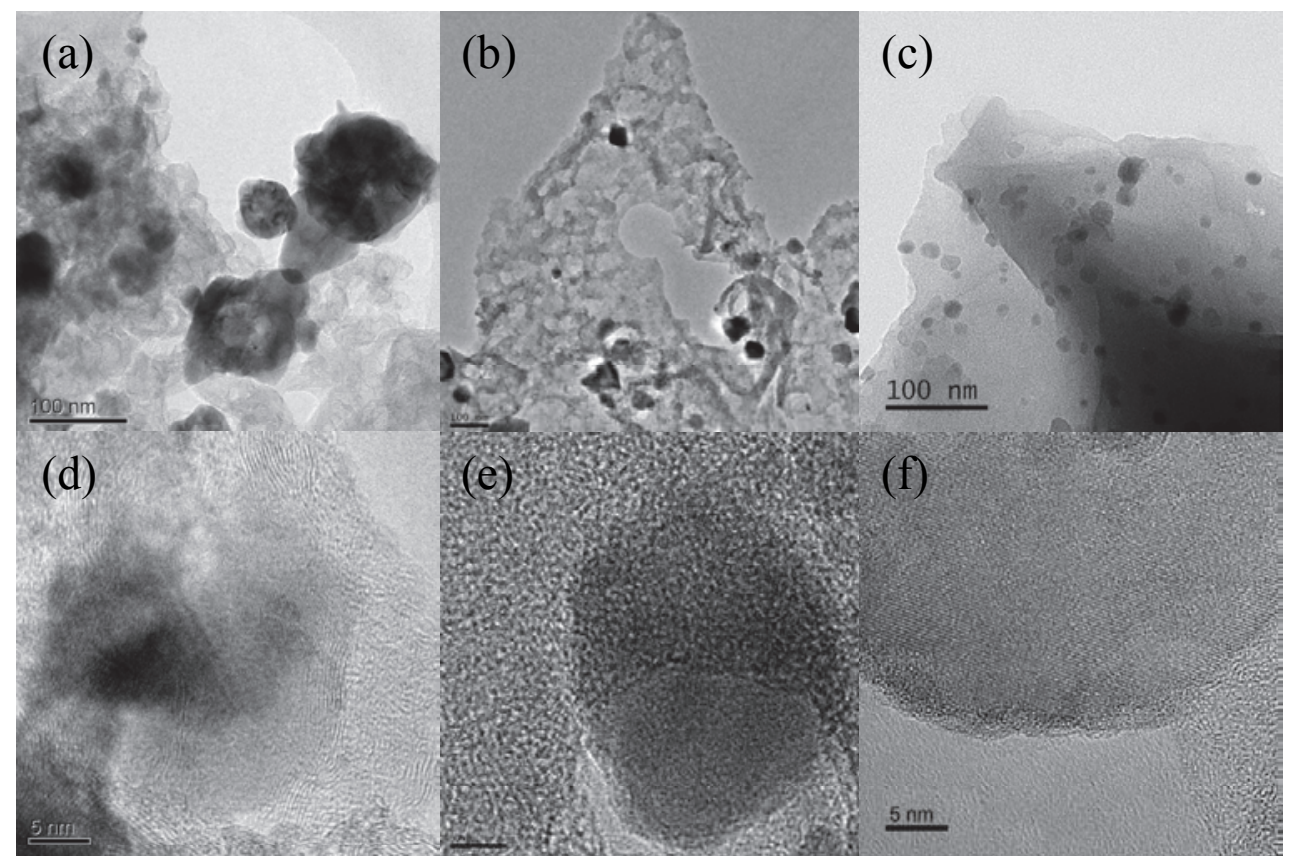

Fig. 3. TEM and HRTEM images of M-N-C. (a, d) Co-N-C; (b, e) Fe-N-C; (c, f) Mn-N-C.

implies more defects in carbon materials [21]. The $I(D) / I(G)$ ratio of the $\mathrm{M}-\mathrm{N}-\mathrm{Cs}(\mathrm{M}=\mathrm{Co}, \mathrm{Fe}, \mathrm{Mn})$ followed the order $\mathrm{Co}-\mathrm{N}-\mathrm{C}$ (1.48) > Fe-N-C (1.19) > Mn-N-C (1.18). This indicated that Co-N-C possessed the highest graphitization degree, which could simultaneously produce more defects than the other samples. The trends of the Raman spectra were consistent with the TG results and TEM images.

\subsection{XPS analysis}

To get the more detailed elemental composition and surface chemical states of the M-N-Cs, XPS analysis was performed. The results are shown in Fig. 5. The full scan of the M-N-Cs presented in Fig. 5(a) revealed the existence of $\mathrm{C}, \mathrm{N}$, and $\mathrm{O}$ and $\mathrm{Co}$, $\mathrm{Fe}$, and Mn. The ratio analysis of the M-N-Cs is presented in Table 2. It can be seen that the atom percent of $C$ decreased in

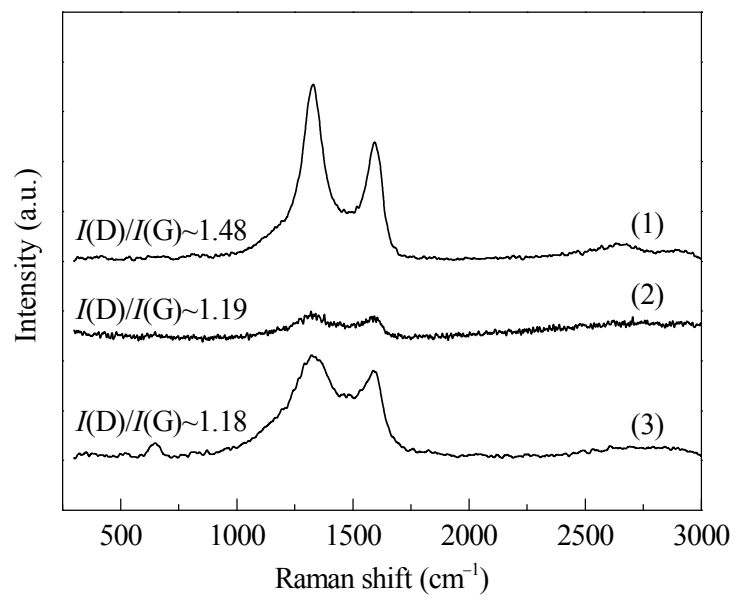

Fig. 4. Raman spectra of M-N-C. (1) Co-N-C; (2) Fe-N-C; (3) Mn-N-C. the order $\mathrm{Co}-\mathrm{N}-\mathrm{C}>$ Fe-N-C $>$ Mn- $-\mathrm{C}$, while the content of $\mathrm{O}$ followed the opposite trend. The metal amounts of Co-N-C and Fe-N-C were similar and larger than that of Mn in Mn-N-C. Besides, the amount of $\mathrm{N}$ was almost the same in Co-N-C and $\mathrm{Fe}-\mathrm{N}-\mathrm{C}$ and a little lower than that in Mn-N-C.

The $\mathrm{C} 1 s$ spectrum was fitted using the following carbon bonding environments: $284.6 \mathrm{eV}(\mathrm{C}=\mathrm{C}), 285.7 \mathrm{eV}(\mathrm{C}=\mathrm{N})$, and $286.6 \mathrm{eV}$ (C-N) (Fig. 5(b)) [22], which suggested the successful doping of $\mathrm{N}$ atoms in the $\mathrm{M}-\mathrm{N}-\mathrm{Cs}$. The high resolution $\mathrm{N} 1 s$ peaks in M-N-C are shown in Fig. 5(c). The N $1 s$ XPS spectrum was deconvoluted into three peaks, namely pyridinic N (398.6 $\mathrm{eV}$ ), pyrrolic $\mathrm{N}$ (399.8 eV), and graphitic $\mathrm{N}$ (401.3 eV) [23]. This indicated that the transition metal type has no obvious effect on the kind of $\mathrm{N}$ species present. However, as shown in Table 2, the ratios of the three types of $\mathrm{N}$ in the $\mathrm{M}-\mathrm{N}-\mathrm{Cs}$ were different. The ratios of pyridinic $\mathrm{N}$ and graphitic $\mathrm{N}$ in Co-N-C were higher than in the others while the pyrrolic $\mathrm{N}$ content was the lowest. Mn-N-C contains the most pyrrolic $\mathrm{N}$ and lowest amount of pyridinic $\mathrm{N}$ and graphitic $\mathrm{N}$ in the $\mathrm{M}-\mathrm{N}-\mathrm{C}$. This showed that the transition metal influences the amount of the different $\mathrm{N}$ species [24].

In the cobalt region (Fig. 5(d)), the band at $778.5 \mathrm{eV}$ was attributed to $\mathrm{Co}^{0}$ [5]. Peaks characteristic of oxidic Co with the typical binding energy of $780.2 \mathrm{eV}$ for the Co $2 p_{3 / 2}$ and $796.2 \mathrm{eV}$ of the Co $2 p_{1 / 2}$ electrons were also found. The shake-up satellite peaks at 784.9 and $802.0 \mathrm{eV}$ suggested that the oxidic Co was mainly composed of $\mathrm{Co}_{3} \mathrm{O}_{4}$ [25]. The low energy bands can be deconvoluted into two peaks with the binding energies of 781.2 and $779.6 \mathrm{eV}$, which represented $\mathrm{Co}^{2+}$ and $\mathrm{Co}^{3+}$, respectively [26]. The deconvolution of the Fe spectrum is shown in Fig. $5(\mathrm{e})$. The peaks with the binding energy of 723.5 and $710.0 \mathrm{eV}$ were attributed to Fe $2 p_{1 / 2}$ and Fe $2 p_{3 / 2}[27,28]$. The low energy bands can be deconvoluted into two peaks with the binding 

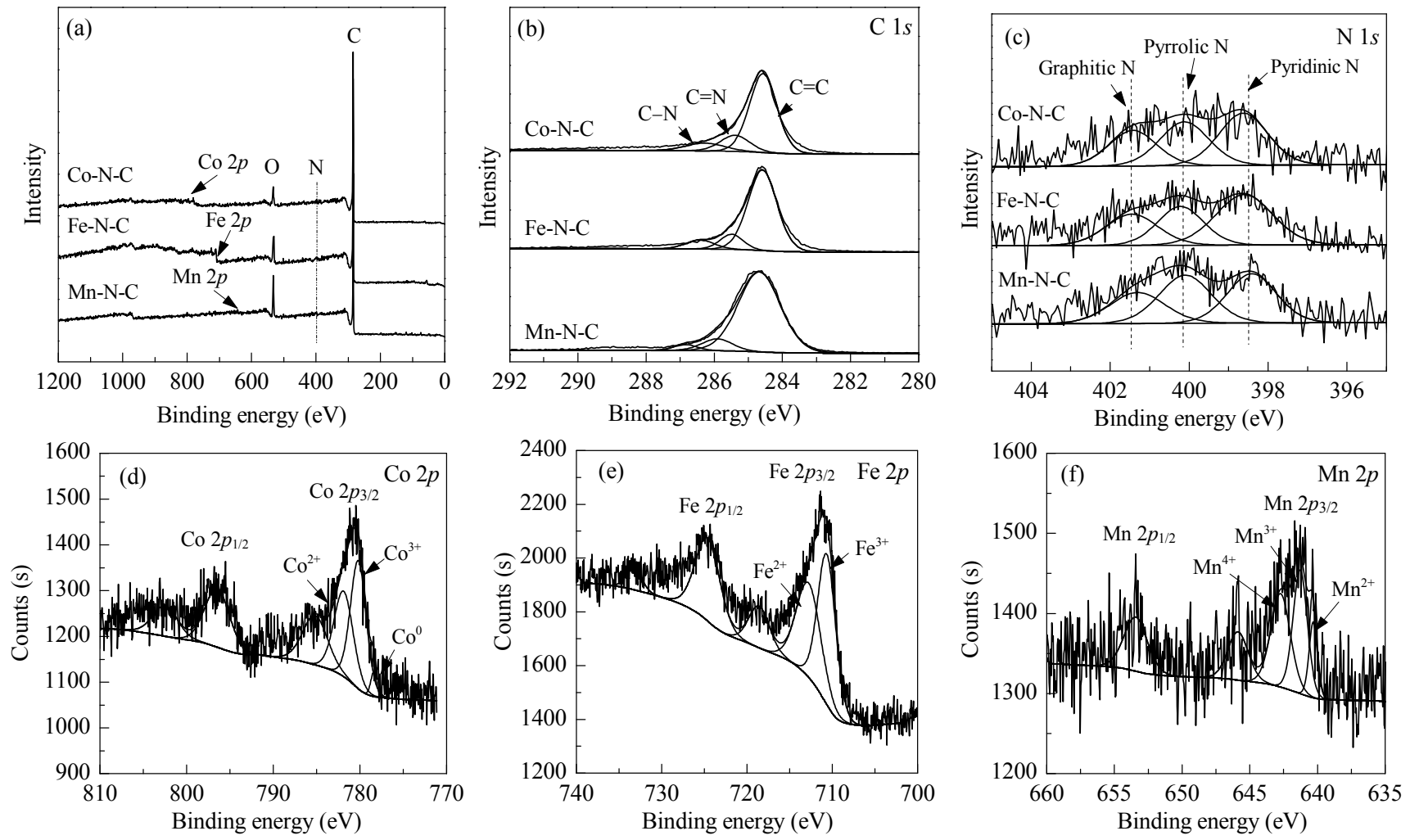

Fig. 5. XPS spectra of M-N-C (M = Co, Fe, Mn) composites. (a) Survey; (b) C 1s; (c) N 1s; (d) Co $2 p$; (e) Fe $2 p$; (f) Mn $2 p$.

Table 2

Ratio analysis of the peaks in the XPS spectra of the M-N-Cs.

\begin{tabular}{|c|c|c|c|c|c|c|c|}
\hline \multirow{2}{*}{ Catalyst } & \multicolumn{4}{|c|}{ Atomic composition (at\%) } & \multicolumn{3}{|c|}{$\mathrm{N}$ content $(\%)$} \\
\hline & $\mathrm{C}$ & 0 & $\mathrm{M}$ & $\mathrm{N}$ & Pyridinic N & Pyrrolic N & Graphitic N \\
\hline $\mathrm{Co}-\mathrm{N}-\mathrm{C}$ & 90.7 & 5.8 & 1.0 & 2.5 & 40.3 & 30.7 & 29.0 \\
\hline $\mathrm{Fe}-\mathrm{N}-\mathrm{C}$ & 87.8 & 8.9 & 1.1 & 2.2 & 37.5 & 36.7 & 25.8 \\
\hline Mn-N-C & 85.1 & 11.1 & 0.6 & 3.2 & 33.2 & 41.0 & 25.8 \\
\hline
\end{tabular}

energies of 712.8 and $710.6 \mathrm{eV}$, which represented $\mathrm{Fe}^{2+}$ and $\mathrm{Fe}^{3+}[29,30]$. In the Mn $2 p$ spectrum (Fig. 5(f)), there were two main peaks, $652.9 \mathrm{eV}$ of $\mathrm{Mn} 2 p_{1 / 2}$ and $640.8 \mathrm{eV}$ of $\mathrm{Mn} 2 p_{3 / 2}$, and a satellite peak at $646.9 \mathrm{eV}$ [2]. The peak of Mn $2 p_{3 / 2}$ can be deconvoluted into three peaks, i.e., $640.3 \mathrm{eV}$ for $\mathrm{Mn}^{2+}, 641.3 \mathrm{eV}$ for $\mathrm{Mn}^{3+}$, and $642.7 \mathrm{eV}$ for $\mathrm{Mn}^{4+}$ [2].

All these observations showed that the M-N-C composites with different transition metals possessed different graphitization degree, and Co-N-C had the most defects and graphitization degree, which are beneficial to the catalytic activity.

\subsection{Catalytic performance of $M-N-C$}

The selective oxidation of ethylbenzene was used as the probe reaction to measure the catalytic performance of the $\mathrm{M}-\mathrm{N}-\mathrm{Cs}$ (Table 3). Co-N-C showed a higher conversion of ethylbenzene (14.1\%) than Fe-N-C (12.4\%) and Mn-N-C $(10.7 \%)$. This may be because of the higher content of Co and the $I(D) / I(G)$ ratio that indicated more defects caused by graphitization. It has been reported that pyridinic $\mathrm{N}$ and graphitic $\mathrm{N}$ are the active sites [31]. Thus it is reasonable to sug- gest that it was the higher content of pyridinic $\mathrm{N}$ and graphitic $\mathrm{N}$ that was beneficial and improved the catalytic performance of Co-N-C. In addition, three consecutive oxidation experiments

Table 3

Catalytic performance of M-N-C for ethylbenzene selective oxidation.

\begin{tabular}{|c|c|c|c|c|c|}
\hline \multirow[b]{2}{*}{ Catalyst } & \multirow{2}{*}{$\begin{array}{c}\text { Recycle } \\
\text { times }\end{array}$} & \multirow{2}{*}{$\begin{array}{c}\text { Conversion of } \\
\text { ethylbenzene } \\
(\%)\end{array}$} & \multicolumn{3}{|c|}{ Selectivity (\%) } \\
\hline & & & $\begin{array}{c}\text { Acetophe- } \\
\text { none }\end{array}$ & $\begin{array}{l}\text { Phenethyl } \\
\text { alcohol }\end{array}$ & $\begin{array}{c}\text { Benzalde- } \\
\text { hyde }\end{array}$ \\
\hline \multirow[t]{3}{*}{ Co-N-C } & 1 & 14.1 & 73.2 & 22.1 & 4.7 \\
\hline & 2 & 12.2 & 72.2 & 21.8 & 6.0 \\
\hline & 3 & 11.5 & 71.7 & 22.4 & 5.9 \\
\hline \multirow[t]{3}{*}{$\mathrm{Fe}-\mathrm{N}-\mathrm{C}$} & 1 & 12.4 & 72.2 & 23.1 & 4.7 \\
\hline & 2 & 12.0 & 67.5 & 26.5 & 6.0 \\
\hline & 3 & 11.7 & 68.4 & 25.5 & 6.1 \\
\hline \multirow[t]{3}{*}{ Mn-N-C } & 1 & 10.7 & 73.7 & 18.3 & 8.0 \\
\hline & 2 & 10.8 & 74.0 & 17.5 & 8.5 \\
\hline & 3 & 10.2 & 74.2 & 17.5 & 8.3 \\
\hline
\end{tabular}

Reaction conditions: catalyst $30 \mathrm{mg}$, ethylbenzene $10 \mathrm{~mL}, \mathrm{O}_{2} 0.8 \mathrm{MPa}$, $120^{\circ} \mathrm{C}, 5 \mathrm{~h}$. 
were performed to demonstrate the stability and reusability of the catalyst. Only slight changes of the catalytic performance in ethylbenzene oxidation was found, which indicated that the $\mathrm{M}-\mathrm{N}-\mathrm{Cs}$ have good recyclability in the heterogeneous catalysis system.

\section{Conclusions}

Transition metal M-N-C ( $\mathrm{M}=\mathrm{Co}, \mathrm{Fe}, \mathrm{Mn})$ catalysts have been synthesized by a template-free method by heating different meso-tetraphenyl porphyrins (CoTPP, $\mathrm{FeTPPCl}$, and $\mathrm{MnTPPCl}$ ) precursors. The M-N-Cs exhibited different catalytic performance for ethylbenzene oxidation. This was ascribed to the difference in $\mathrm{M}(\mathrm{Co}, \mathrm{Fe}, \mathrm{Mn})$ and their catalytic behavior during $\mathrm{M}-\mathrm{N}-\mathrm{C}$ formation. A higher cobalt content, higher $I(\mathrm{D}) / I(\mathrm{G})$ ratio (meaning more defects caused by graphitization), and more pyridinic $\mathrm{N}$ and graphitic $\mathrm{N}$ species were beneficial for improving the catalytic performance of Co-N-C. All the M-N-C composites had remarkable recyclability in the selective oxidation of ethylbenzene.

\section{References}

[1] K. A. Kuttiyiel, Y. M. Choi, S. M. Hwang, G. G. Park, T. H. Yang, D. Su, K. Sasaki, P. Liu, R. R. Adzic, Nano Energy, 2015, 13, 442-449.

[2] X. C. Wang, X. R. Liu, Y. Xu, G. M. Peng, Q. Cao, X. D. Mu, Chin. J. Catal., 2015, 36, 1614-1622.

[3] J. C. Zhang, J. X. Guo, W. Liu, S. P. Wang, A. R. Xie, X. F. Liu, J. Wang, Y. Z. Yang, Eur. J. Inorg. Chem., 2015, 2015, 969-976.

[4] C. Domínguez, F. J. Pérez-Alonso, M. Abdel Salam, J. L. G. de la Fuente, S. A. Al-Thabaiti, S. N. Basahel, M. A. Peña, J. L. G. Fierro, S. Rojas, Int. J. Hydrogen Energy, 2014, 39, 5309-5318.

[5] H. Y. Jin, J. Wang, D. F. Su, Z. F. Wei, Z. F. Pang, Y. Wang, J. Am. Chem. Soc., 2015, 137, 2688-2694.

[6] R. V. Jagadeesh, H. Junge, M. M. Pohl, J. Radnik, A. Brückner, M. Beller, J. Am. Chem. Soc., 2013, 135, 10776-10782.
[7] I. Matanovic, S. Babanova, A. Perry III, A. Serov, K. Artyushkovaa, P. Atanassov, Phys. Chem. Chem. Phys., 2015, 17, 13235-13244.

[8] J. Masa, W. Xia, I. Sinev, A. Q. Zhao, Z. Y. Sun, S. Grutzke, P. Weide, M. Muhler, W. Schuhmann, Angew. Chem. Int. Ed., 2014, 53, 85088512.

[9] R. Othman, A. L. Dicks, Z. H. Zhu, Int. J. Hydrogen Energy, 2012, 37, 357-372.

[10] D. F. Su , J. Wang, H. Y. Jin, Y. T. Gong, M. M. Li, Z. F. Pang, Y. Wang, J. Mater. Chem. A, 2015, 3, 11756-11761.

[11] I. Herrmann, U. I. Kramm, S. Fiechter, P. Bogdanoff, Electrochim. Acta, 2009, 54, 4275-4287.

[12] S. L. Gojkovic, S. Gupta, R. F. Savinell, Electrochim. Acta, 1999, 45, 889-897.

[13] Z. G. Liu, L. T. Ji, X. L. Dong, Z. Li, L. L. Fu, Q. A. Wang, RSC Adv., 2015, 5, 6259-6264.

[14] Z. G. Liu, L. T. Ji, J. Liu, L. L. Fu, S. F. Zhao, J. Mol. Catal. A, 2014, 395, 315-321.

[15] D. H. Shen, L. T. Ji, Z. G. Liu, W. B. Sheng, C. C. Guo, J. Mol. Catal. A, 2013, 379, 15-20

[16] H. Jin, H. M. Zhang, H. X. Zhong, J. L. Zhang, Energy Environ. Sci., 2011, 4, 3389-3394.

[17] L. L. Fu, Y. Chen, Z. G. Liu, J. Mol. Catal. A, 2015, 408, 91-97.

[18] A. A. Costa, G. F. Ghesti, J. L. de Macedo, V. S. Braga, M. M. Santos, J. A. Dias, S. C. L. Dias, J. Mol. Catal. A, 2008, 282, 149-157.

[19] F. Yang, S. Y. Gao, C. R. Xiong, H. Q. Wang, J. Chen, Y. Kong, Chin. J. Catal., 2015, 36, 1035-1041.

[20] Y. J. Gao, G. Hu, J. Zhong, Z. J. Shi, Y. S. Zhu, D. S. Su, J. G. Wang, X. H. Bao, D. Ma, Angew. Chem. Int. Ed., 2013, 52, 2109-2113.

[21] Y. L. Li, J. J. Wang, X. F. Li, J. Liu, D. S. Geng, J. L. Yang, Electrochem. Commun., 2011, 13, 668-672.

[22] Y. H. Su, Y. H. Zhu, H. L. Jiang, J. H. Shen, X. L. Yang, W. J. Zou, J. D. Chen, C. Z. Li, Nanoscale, 2014, 6, 15080-15089.

[23] J. Wang, G. X. Wang, S. Miao, X. L. Jiang, J. Y. Li, X. H. Bao, Carbon, 2014, 75, 381-389.

[24] H. S. Oh, H. Kim, J. Power Sources, 2012, 212, 220-225.

[25] C. V. Schenck, J. G. Dillard, J. W. Murray, J. Colloid Interface Sci., 1983, 95, 398-409.

[26] E. Puello-Polo, J. L. Brito, J. Mol. Catal. A, 2008, 281, 85-92.

\section{Graphical Abstract}

Chin. J. Catal., 2016, 37: 398-404 doi: 10.1016/S1872-2067(15)61029-4

Influence of the metal sites of $\mathrm{M}-\mathrm{N}-\mathrm{C}(\mathrm{M}=\mathrm{Co}, \mathrm{Fe}, \mathrm{Mn})$ catalysts derived from metalloporphyrins in ethylbenzene oxidation

Lingling Fu, Yijuan Lu, Zhigang Liu*, Runliang Zhu

Hunan University; Guangzhou Institute of Geochemistry, Chinese Academy of Sciences

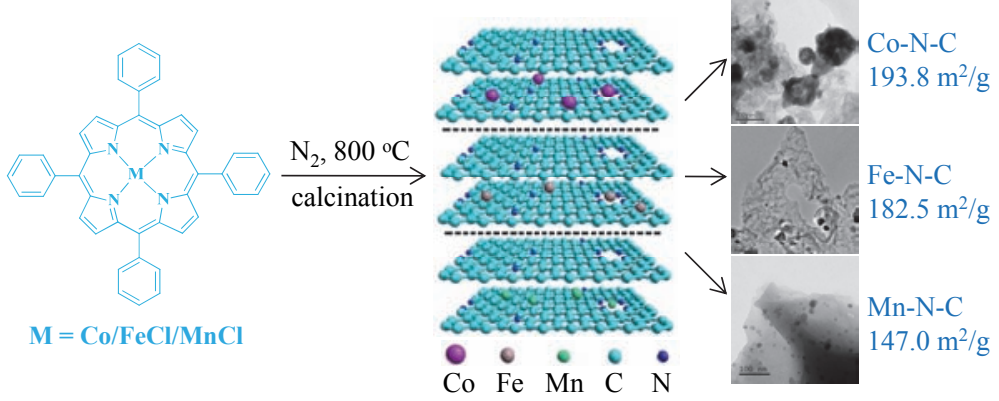

$\mathrm{M}-\mathrm{N}-\mathrm{C}(\mathrm{M}=\mathrm{Co}, \mathrm{Fe}, \mathrm{Mn})$ catalysts synthesized by heating meso-tetraphenyl porphyrins (i.e. CoTPP, FeTPPCl, and MnTPPCl) have different calcination degree which was caused by the different catalytic activity of the metal sites during the heating of the metalloporphyrins. 
[27] Y. Chen, S. F. Zhao, Z. G. Liu, Phys. Chem. Chem. Phys., 2015, 17, 14012-14020.

[28] Y. Yao, B. Q. Zhang, J. Y. Shi, Q. H. Yang, ACS Appl. Mater. Interfaces, 2015, 7, 7413-7420.

[29] L. L. Geng, M. Zhang, W. X. Zhang, M. J. Jia, W. Yan, G. Liu, Catal. Sci.
Technol., 2015, 5, 3097-3102.

[30] L. L. Geng, X. Y. Zhang, W. X. Zhang, M. J. Jia, G. Liu, Chem. Commun., 2014, 50, 2965-2967.

[31] S. Pylypenko, S. Mukherjee, T. S. Olson, P. Atanassov, Electrochim. Acta, 2008, 53, 7875-7883.

\title{
以卟啉为前驱体制备的 M-N-C $(M=\mathrm{Co}, \mathrm{Fe}, \mathrm{Mn})$ 催化剂中 不同过渡金属中心对催化乙苯氧化反应的影响
}

\author{
付玲玲 ${ }^{\mathrm{a}}$, 鲁怡娟 ${ }^{\mathrm{a}}$, 刘志刚 ${ }^{\mathrm{a}}{ }^{*}$, 朱润良 ${ }^{\mathrm{b}}$ \\ a 湖南大学化学化工学院生物与传感国家重点实验室, 湖南长沙 410082 \\ $\mathrm{b}$ 中国科学院广州地球与化学研究所, 广东广州 510640
}

摘要: 近年来, 过渡金属氮碳材料由于其廉价、高效与持久耐用的性质得到广泛研究, 被视为钯基催化剂的良好替代品. 除 了可应用于电催化领域, 过渡金属氮碳材料还可作为有机反应催化剂, 并显示出良好的催化性能. 金属吓啉化合物因其高 效模拟自然酶的仿生催化功能而闻名, 然而在均相催化体系中其难回收、易自我氧化失活的缺点大大阻碍了其实际应用. 对金属卟啉进行热处理是提高其催化性能与稳定性的有效方法. 此外, 作为内部含有金属-氮配合键的含碳大环化合物, 金 属卟啉是一步合成金属氮碳材料的良好前驱体. 本课题组已证明以金属钴卟啉作为前驱体制得的金属氮碳催化剂具有良 好的催化乙苯氧化性能.

在此基础上,本文采用含有不同过渡金属中心的四苯基金属卟啉(四苯基钴卟啉、四苯基铁卟啉和四苯基钴卟啉)为前 驱体, 通过无模板法热处理制备了过渡金属氮碳催化剂 M-N-C (M = Co, Fe, Mn), 考察不同过渡金属中心对催化剂性能的 影响. 所得催化剂采用 $\mathrm{N}_{2}$ 吸附-脱附、热重 (TG)、透射电子显微镜 (TEM)、高分辨透射电子显微镜 (HRTEM)、拉曼光谱 (Raman) 和 X 射线光电子能谱进行了表征. $\mathrm{N}_{2}$ 吸附-脱附结果表明, 所得 M-N-C 材料具有不同的比表面积与孔道结构, 其 中 Co-N-C 催化剂比表面积最大. TG 显示, 不同金属卟啉的失重情况不同, 四苯基钴卟啉失重最多, 四苯基铁卟啉次之, 四 苯基锰卟啉失重最少. 从 TEM 和 Raman 结果可见, 所得不同金属氮碳材料具有不同的石墨化程度, 其中 Co-N-C 材料具 有明显的石墨化层状碳结构, 石墨化程度最高, Fe-N-C 材料次之, 而 Mn-N-C 材料中的碳主要呈片状无定形状态, 表明其 石墨化程度最低. 这可能是不同过渡金属中心在加热过程中对卟啉结构碳化过程催化效果不同所致, 其中钴中心对卟啉 结构碳化过程的催化效果最佳.

另外, 考察了该 M-N-C 催化剂在无溶剂条件下催化分子氧选择性氧化乙苯的性能. 结果发现, 不同金属中心的 M-N-C 催化剂表现出不同的催化性能. 这可能归因于金属种类的不同、所得催化剂碳氮结构的差别以及金属中心与氮碳结构的 协同效应. 此外, 这些 M-N-C 材料作为多相催化剂在以氧气为氧源的无溶剂选择性氧化乙苯反应中表现出良好的催化性 能, 且多次使用后没有明显的活性损失, 具有良好的回收使用性能.

关键词：过渡金属(钴、铁、锰)氮碳催化剂；过渡金属；氮掺杂碳材料；卟啉；乙苯氧化

收稿日期: 2015-10-15. 接受日期: 2015-11-24. 出版日期: 2016-03-05.

*通讯联系人. 电话: (0731)88823327; 电子信箱: liuzhigang@hnu.edu.cn

基金来源：国家自然科学基金 $(21103045,1210040,1103312)$; 中国石油大学重质油国家重点实验室 (SKCHOP201504); 中国科学 院广州地球与化学研究所中国科学院矿物学与成矿学重点实验室 (KLMM20150103).

本文的英文电子版由Elsevier出版社在ScienceDirect上出版(http://www.sciencedirect.com/science/journal/18722067). 